\title{
НОВИЙ ЗДОБУТОК КОГНІТИВНОЇ ТЕОРІї ПЕРЕКЛАДУ
}

Засєкін С. Психолінгвістичні універсалії перекладу художнього тексту / Волин. нац. ун-т ім. Лесі Українки. - Луцьк, 2012. - 275 с.

Когнітивна теорія перекладу - порівняно молодий напрям досліджень, який доволі недавно почав активно розвиватися в рамках когнітивної лінгвістики. Звісно, низка суголосних ідей висловлювали ще німецькі філософи мови, а Олександр Потебня підняв до висот опрацювання взаємозв'язків між мовою і мисленням. Однак відродження когнітивного підходу - уже як противаги до ідеології структуралізму - пов'язують з іменами Джона Серля, Джорджа Лакофа, Джона Злобіна, Леонарда Талмі, Роналда Ленекера в останній чверті $\mathrm{XX}$ ст. В українських умовах когнітивізм інколи збагачується дивними екстраполяціями та запозиченнями із структуралізму, що в суті суперечить основам когнітивного сприйняття мови (приміром, ужиток термінів і понять “сема / семема”, “денотація / конотація”, що є теоретично неприпустимим). Водночас, варто інколи обгрунтовувати своєрідне, неканонічне - позірно хибне - розуміння та інтерпретацію певних понять, які із суто конвенційних мотивів допомагають краще описати мовні явища, як-от трапляється в перекладознавчих розглядах. Тому настільки важливі монографічні праці з вивчення когнітивних процесів у перекладі.

Монографія доцента Східноєвропейського національного університету імені Лесі Українки Сергія Засєкіна "Психолінгвістичні універсалії перекладу художнього тексту" присвячена майже невивченій тематиці в українському перекладознавстві - процесу перекладу, де залучалися б психолінгвістика, когнітивна психологія та нейрологія. Процесуальні студії у Скандинавії та Іспанії дали досить цікаві результати, а монографія луцького колеги обгрунтовує та розвиває внесок українських науковців.

Книга С. Засєкіна складається з п'яти частин. Два перші розділи підсумовують погляди українських, радянських та закордонних учених на психолінгвістичні основи процесу перекладу та їхнє значення для визначення критеріїв адекватності й інтерпретації. Зустрічаємо тут грунтовний опис найважливіших концепцій - когнітивізму, конекціонізму та функціоналізму.

Центральною частиною книги є третій розділ, який розкриває психолінгвістичну модель художнього перекладу. Модель побудовано на принципах менталізму символістської парадигми й емпіризму конекціонізму, а тому вона обгрунтовує одночасні темпорально-дискретні та просторово-цілісні шляхи обробки інформації. Усі компоненти й частини моделі погруповано у три блоки - когнітивний, афективний та конативний, а також деталізовано їхні взаємозв'язки у схемі (стор. 71). Оце схематичне підсумування є наріжним каменем концепції автора, яке є спробою систематизувати ті процеси, яких ми не бачимо й бачити наразі не можемо. Для цього дослідникові довелося акумулювати всі аналітичні знаряддя для доведення своєї концепції, і він занурюється в ряд проективних і квантитативних методів, а також звертається до інтроспекції як методу аналізу. Такий підхід уможливив формулювання універсалій, їх розмежування на “загальні” й “емпіричні” та виділення конкретних одиниць у цих групах і підгрупах.

Останні дві частини розглядають різні типи універсалій на різних рівнях пропонованої моделі. Дослідник вдається до чималої кількості квантитативних та інтроспективних опера-

(C) Шмігер T., 2014 
цій та обгрунтовує аналітичні результати на широкому спектрі художніх текстів. Останній розділ особливо тяжко читати непідготовленому читачеві. Математичні розрахунки, схеми та діаграми створюють дуже добру наочність, але, щоб простежити їхню істинну цінність, простіше кажучи, щоб провести власну верифікацію, т читач повинен бути добре обізнаний у сучасних когнітивістичних / психолінгвістичних / нейрологічних дослідженням і в системах моделювання.

Повертаючись до самої психолінгвістичної моделі художнього перекладу, хочеться звернути увагу на обминанні культурного компоненту у процесі пізнання й комунікації. Леонард Талмі обгрунтовує вагомість саме культурної когнітивної системи на рівні із іншими когнітивними системами (як-от сприйняття, мотивування, чуттєвість, увага, пам'ять, планування і мова), які формують певну поведінку, яку треба сприймати як єдність практики та дискурсу (Talmy L. Toward a Cognitive Semantics. Vol.2. P. 377, 379). Певна кореляція такої системи у пропонованій моделі все ж присутня в компоненті “енциклопедичні знання”, хоча ії варто було б поглибити.

Монографія закінчується висновками й додатками, а найбільше радує око розширена англомовна анотація, що викладає основні твердження монографії і запрошує світових дослідників до української наукової школи.

Віримо, що ця монографія викличе чимало корисних і потрібних дискусій, з яких виростатимуть нові статті, збірники, монографії.

Тарас Шмігер 